Tohoku J. exp. Med., 1975, 116, 201-202

Short Report

\title{
FSH, LH and Testosterone Levels in Human Seminal Plasma
}

\author{
masafumi Shirai, Shotaro Matsuda, Shiro Mitsukawa, \\ Mamoru Nakamura* and Kenzo Yonezawa $†$ \\ Department of Urology, Department of Radiology* and Hospital \\ Pharmacy, $\dagger$ Tohoku University School of Medicine, Sendai
}

Smrrai, M., Matsuda, S., Mrtsukawa, S., Nakamura, M. and Yonezawa, K. FSH, LH and Testosterone Levels in Human Seminal Plasma. Tohoku J. exp. Med., 1975, 116(2), 201-202-Testosterone levels in the seminal plasma of 5 normal males, and 30 male sterility patients were measured by radioimmunoassay. In 9 random cases, seminal plasma levels of FSH and LH were determined by radioimmunoassay. The average level of seminal plasma testosterone for the normal males was $72 \pm 52 \mathrm{ng} / 100 \mathrm{ml}$, higher than that of the patients: $52 \pm 4 \mathrm{ng} /$ $100 \mathrm{ml}$. The average levels of FSH and LH in the seminal plasma of the 9 random cases were $4.4 \pm 2.0 \mathrm{mIU} / \mathrm{ml}$ and $35.4 \pm 5.4 \mathrm{mIU} / \mathrm{ml}$, respectively. —— FSH; LH; seminal plasma; testosterone

Semen contains various enzymes and hormones, but an exact assay of a particular seminal plasma hormone has been generally considered impossible because of their microvolume. However, recent developments in radioimmunoassay and other advanced microassay methods have made determination of a variety of hormones possible.

The followings are the results of radioimmunoassays of follicle stimulating hormone (FSH), luteinizing hormone (LH) and testosterone in human seminal plasma.

The seminal plasma assayed was from the semen of 30 male sterility patients, ranging between 25 and 42 years old, seen in the outpatient clinic, Department of Urology, Tohoku University Hospital, and 5 other normal subjects between 26 and 30 years old. The male sterility patients included 22 cases of oligospermia ( 3 with $50 \times 10^{8} / \mathrm{ml}$ or more in sperm count, 7 with $20-49 \times 10^{8} / \mathrm{ml}$, and 12 with $1-19 \times 10^{6} / \mathrm{ml}$ ) and 8 cases of azoospermia. Seminal plasma levels of testosterone were measured in all cases, and separately FSH and LH in $\mathbf{9}$ random cases, using radioimmunoassay. The methods of radioimmunoassay employed were for FSH and LH that were developed by Yonezawa et al. (1973) using 2 antibodies, and for testosterone that of Shirai et al. (1974).

In the 5 normal cases, the seminal plasma levels of testosterone ranged from 23 to 148 $\mathrm{ng} / 100 \mathrm{ml}$, averaging $72 \pm 52 \mathrm{ng} / 100 \mathrm{ml}$ (Table 1). Average blood plasma levels of testosterone were $628 \pm 236 \mathrm{ng} / 100 \mathrm{ml}$ for normal males and $36 \pm 1.9 \mathrm{ng} / 100 \mathrm{ml}$ for normal females.

In the 30 sterility patients, the seminal plasma testosterone levels were $6-178 \mathrm{ng} / 100 \mathrm{ml}$, averaging $52 \pm 41 \mathrm{ng} / 100 \mathrm{ml}$, which was lower than normal. The comparative levels of seminal plasma testosterone in the patients were $6-152 \mathrm{ng} / 100 \mathrm{ml}$, averaging $51 \pm 35$ $\mathrm{ng} / 100 \mathrm{ml}$ for the oligospermia cases, vs. $13-178 \mathrm{ng} / 100 \mathrm{ml}$, averaging $61 \pm 57 \mathrm{ng} / 100 \mathrm{ml}$ for the azoospermia cases. This mean level for the azoospermia group was higher than that for the oligospermia, but lower than the normal average of $72 \pm 52 \mathrm{ng} / 100 \mathrm{ml}$.

Received for publication, March 11, 1975. 
TABLE 1. Testosterone levels in human seminal plasma, normal males and male sterility patients

\begin{tabular}{lc}
\hline & $\begin{array}{c}\text { Seminal plasma testosterone } \\
(\mathrm{ng} / 100 \mathrm{ml})\end{array}$ \\
\hline $\begin{array}{l}\text { Normal males } \\
\text { Mean } \pm \text { S.D. }(n=5)\end{array}$ & $72 \pm 52$ \\
$\begin{array}{l}\text { Oligospermia } \\
\text { Mean } \pm \text { S.D. }(n=22)\end{array}$ & $51 \pm 35$ \\
$\begin{array}{l}\text { Azoospermia } \\
\text { Mean } \pm \text { S.D. }(n=8)\end{array}$ & $61 \pm 57$ \\
$\begin{array}{l}\text { Total cases of } \\
\text { male sterility } \\
\text { Mean } \pm \text { S.D. }(n=30)\end{array}$ & $52 \pm 41$ \\
\hline
\end{tabular}

TABLE 2. FSH and LH levels in human seminal plasma, male sterility patients

\begin{tabular}{lcc}
\hline & FSH $(\mathrm{mIU} / \mathrm{ml})$ & LH $(\mathrm{mIU} / \mathrm{ml})$ \\
\hline Mean \pm s.D. $(\mathrm{n}=9)$ & $4.4 \pm 2.0$ & $35.4 \pm 5.4$ \\
\hline
\end{tabular}

In the seminal gonadotropin in the 9 random cases from the 30 male sterility patients, FSH levels ranged from 1.8 to $8.3 \mathrm{mIU} / \mathrm{ml}$, averaging $4.4 \pm 2.0 \mathrm{mIU} / \mathrm{ml}$, while $\mathrm{LH}$ levels were $27.5-44.0 \mathrm{mIU} / \mathrm{ml}$, averaging $35.4 \pm 5.4 \mathrm{mIU} / \mathrm{ml}$ (Table 2). In normal males, the average blood plasma level of $\mathrm{FSH}$ was $7 \pm 4 \mathrm{mIU} / \mathrm{ml}$, and $\mathrm{LH}$ was $10 \pm 7 \mathrm{mIU} / \mathrm{ml}$.

Thus, in our tests the levels of gonadotropin, particularly the LH, in the seminal plasma of the male sterility appeared to be higher than those in the blood plasma of normal males. Also the testosterone levels in the seminal plasma were generally higher than those in normal female blood plasma.

\section{References}

1) Shirai, M., Matsuda, S., Nakamura, M. \& Yonezawa, K. (1974) A simplified radioimmunoassay for plasma testosterone. Jap. J. clin. Urol. (Jap.), 25, 269-273.

2) Yonezawa, K., Nakamura, M., Shirai, M. \& Matsuda, S. (1973) Measurement of plasma FSH and LH in male gonadal dysfunction with use of HFSH and HLH radioimmunoassay kit. Acta Urol. Jap. (Jap.), 19, 611-616. 